\title{
Risk Factors of Academic Underachievement among Preparatory School Students in El-Behira Governorate
}

\author{
Naglaa Kamel Abduallah Hussein ${ }^{1, *}$, Marwa Mohamed Ahmed Ouda ${ }^{2}$ \\ ${ }^{1}$ Community Health Nursing Department, Faculty of Nursing, Damanhour University, Damanhour, Egypt \\ ${ }^{2}$ Pediatric Nursing Department, Faculty of Nursing, Damanhour University, Damanhour, Egypt \\ *Corresponding author: nogakamel55@yahoo.com
}

Received August 12, 2018; Revised September 29, 2018; Accepted October 08, 2018

\begin{abstract}
Background: Adolescence is a period of considerable physical and mental changes, of which transition to higher levels of study and planning for a future career is significant. Academic achievements assume importance and is a key factor for personal progress and personal worth and it considered a benchmark of a child's intelligence. In today's competitive society, Academic underachievement is a major concern among parents and teachers, and it assumes significance as it is a key factor for personal and professional growth. Aim of study: Is to identify risk factors of academic underachievement among preparatory school students in El-Behira Governorate. Design: Descriptive design. Setting: The study was conducted in ten (10) governmental preparatory schools in five (5) educational directorates of the eighteen (18) educational directorates in El-Beheira Governorate Subjects: using systematic random sample technique to select the required sample size of 400 students (200 achievers and 200 underachievers) which were halved by sex. Tools: data was collected using two tools for Students assessment, Family Socioeconomic Status Scale (SES) and Strengths and Difficulties Questionnaire (SDQ). Results: according to the liner regression model for the predictors of academic achievement among the studied students the following variables show a significant effect, Students' age, Socioeconomic score, Students' labor, Finishing daily homework, Private tutoring, Years of previous grade repetition and total strengths and difficulties score. Conclusion and recommendations: Several personal risk factors were highlighted at the present study to have significant association with students' underachievement so it is recommended to Developing evidence based guidelines for underachievement based on the underlying causes and awareness of the community about adolescents' underachievement in schools.
\end{abstract}

Keywords: adolescence, risk factors, life style, school performance, academic underachievement, academic achievement

Cite This Article: Naglaa Kamel Abduallah Hussein, and Marwa Mohamed Ahmed Ouda, "Risk Factors of Academic Underachievement among Preparatory School Students in El-Behira Governorate." American Journal of Nursing Research, vol. 6, no. 6 (2018): 418-429. doi: 10.12691/ajnr-6-6-9.

\section{Introduction}

Adolescents are energetic generation who will play a vital role in the next decade of human development. They are the resource of any country so, investing on their education and health through provision of supportive environment at home, school and community is essential for future development. Globally, there are one in every six people in the world is an adolescent, just about 1.2 billion, nearby $85 \%$ live in developing countries and the rest lives in the developed world. Adolescents in Egypt are about 17 million, demonstrating around $19.1 \%$ of the total population, and represent even larger proportion of the nation's human potential. [1,2,3]

Adolescents' education is imperative from both societal and individual perspective. From a societal point of view, educated citizens are necessary to increase a nation's standard of living and future development and achievement of the international goals. On the individual level, education accumulates knowledge, cognitive and motor skills and experiences, resources and habits. These shape personal control, healthy lifestyles, income, employment, interpersonal relations and social support. Moreover, education has an impact on subjective outcomes such as happiness and perceived quality of life. $[4,5]$

In Egypt, the education system obligates a nine years of compulsory education; including two stages (six years of primary and three years of preparatory education). The transition between these two stages can confront the growing adolescents with new social and educational demands which play a major role in shaping their educational performance and may contribute to academic underachievement. [6]

Academic underachievement of adolescents is a vast concern among parents and teachers in present day competitive society. In general, it is known as failure to meet the academic requirements of the school. Literary, it 
is most commonly defined as a discrepancy between potential (ability) and performance (achievement) that not result from diagnosed learning disability and must be a condition that present over an extended period. [7,8]

Academic underachievement is a global epidemic, particularly in developing countries and poor urban areas. It is estimated that in many developing countries, the share of any cohort that completes lower secondary education and passes at least a low benchmark of basic literacy in cognitive skills is below one person in ten. [9]

Based on Survey of Young People in Egypt (SYPE) data $2011,17.1 \%$ of students who are currently attending schools experience grade repetition, the largest proportion of them were in preparatory schools as they constituted $11.4 \%$ of them. [10]

According to El-Beheira Governorate Ministry of Education, General Administration for Information and Statistics; the total rate of academic underachievement among preparatory school students in the academic year 2014-2015 was $38.2 \%$ which was higher in boys $(40.2 \%)$ than girls (36.4\%). [11]

Academic underachievement is a complex problem with interrelated and multi-level factors contributing to its development, compounding and exacerbating the problem. Such factors are within the adolescent himself, there are several individual characteristics and health factors that have significantly predicted academic achievement. Concerning the individual characteristics; adolescents differ from each other in the way in which they cope with their problems and therefore manifest various personality characteristics, some of which may result in underachievement. Such characteristics include; low selfconcept, self-esteem, motivation, locus of control, poor self-regulation skills, poor study habits, and negative attitude toward education and learning. Topping this list is poor self-image as underachievers don't have an innate capacity to do well and the slightest negative experience regarding their performance will weaken their resolve even further and the cycle goes on. Moreover, poor health, poor dietary habits, exposure to violence, and students engaged in labor can influence students' academic performance through detracting their cognitive stimulation, physical energy, concentration in school materials, test scores, attendance, classroom behavior, and graduation rates. [12,13].

Family as a social unit is an essential determinant for modeling one's mental capacities along with their physical and social structure. Lower socioeconomic status and lower levels of parents' education can negatively influence their adolescents' academic performance either by physical or psychological unavailability of parents or deficient supportive educational resources. [14]

An important psychosocial drive that emerges during adolescence is the growing need for peer group affiliation as adolescents seek to decrease their dependence on family and be more autonomous. Peer group primarily assist with socialization and construction of identity. It is usually relatively homogenous and desires a degree of conformity to its norms; so the underachiever student may be alienated by the social group as any deviation may be met with group resistance and negative perception resulting in rejection and isolation. [15]

Academic underachievement not only affects the underachiever students, but also their families, teachers and all school members and the community as a whole. Students enter a vicious cycle of failure that can contribute to several behavioral and emotional problems as loss of self-confidence and feeling of being unworthy person for successful life. It also can lead to, school dropout and unemployment or employment with lower wags later in life. In relation to parents, their child's failure can contribute to several emotional and financial problems in addition to the social stigma of having an underachiever student. As regard teacher, students' misunderstanding of their lessons affects his self-confidence as a successful teacher. School leadership also suffers from underachiever students as they impede the educational process and worsen the school results. Furthermore, underachievement can drain the whole community human and economic resources. [16,17]

Today's the school nurse is often a part of an interdisciplinary school team where she has a pivotal role in reducing barriers to learning through playing a variety of roles. School health nurse can work collaboratively to provide effective counseling strategies that are based on accurate assessment of the underachiever student to tackle the underlying causes of underachievement. Also, she can widen the nursing base of knowledge about adolescent students and their school performance problems within the school setting. Moreover she works to promote "safe haven" where students can learn and be safe. [18,19]

At the national level there are very scarce studies carried out upon underachiever students including; a study to assess the possible contributing and precipitating factors of underachievement among primary school children was carried out in Cairo in 1983. Another study of the epidemiology of academic underachievement also among primary school children was done in Alexandria in 1999. These studies were conducted with no emphasis on the ecological interactions among multilevel risk factors of academic underachievement during adolescence. Therefore, this study aimed to studying the risk factors of academic underachievement among preparatory school students in El-Beheira Governorate. [20,21]

The research question of this study was:

What are the risk factors of academic underachievement among preparatory school students in El-Beheira Governorate?

\section{Material and Methods}

\subsection{Material}

\subsubsection{Research Design}

Descriptive study design was adopted to carry out this study.

\subsubsection{Setting}

The study was conducted in ten (10) governmental preparatory schools in five (5) educational directorates of the eighteen (18) educational directorates in El-Beheira Governorate as illustrated in Table 1.

\subsubsection{Subjects}

The target population of this study was two groups of achiever and underachiever students enrolled in the 
second and third grades in the selected governmental preparatory schools in El-Beheira Governorate. The students included in the study fulfilled the following eligibility criteria:

1. Aged 12 years or more.

2. Underachiever students with grades $<60 \%$ in the annual exam of the preceding year

3. Achiever students with grades $\geq 60 \%$ in the annual exam of the preceding year.

- Using the multistage sampling technique, the following steps were conducted to select the students:-

- Five out of the 18 educational directorates in El-Beheira Governorate were randomly selected

- From each directorate, one male and one female preparatory school were chosen randomly.

- From each school, 40 students (20 underachievers and 20 achievers) enrolled in the second and third grades were included in the study using systematic random sample technique to select the required sample size of 400 students (200 underachiever and 200 achiever students) which was halved by sex.

- The sample size was calculated by using EPI info7software based on the total population of 152215 ( number of students enrolled in the second and third academic year 2016-2017 of preparatory schools) and an estimated expected frequency of $17 \%$ of underachievement with an acceptable error of $5 \%$ and confidence limit of $99 \%$. This resulted in minimum required sample size of 381 students. The final sample size used was 400 students to compensate for possible nonresponse.

Table 1. Names of governmental preparatory school

\begin{tabular}{|c|c|c|}
\hline \multirow{2}{*}{$\begin{array}{l}\text { The study } \\
\text { directorates }\end{array}$} & \multicolumn{2}{|c|}{ School name } \\
\hline & Male schools & Female schools \\
\hline $\begin{array}{l}\text { 1. Bandar } \\
\text { Damanhour }\end{array}$ & Ahmed Moharam & ElHadisa \\
\hline 2. Etay Elbaroad & Magda El Serafy & Abd-Elhady El Saka \\
\hline 3. Abo Homus & Mohamed Abo Rawash & Abd ElAziz Makhyon \\
\hline 4. Edko & El Sayed Abd Elgelil & Bear Elhelo \\
\hline 5. Shobrakheit & $\begin{array}{l}\text { Naser preparatory } \\
\text { school for boys }\end{array}$ & $\begin{array}{l}\text { Shobrakheit preparatory } \\
\text { school for girls }\end{array}$ \\
\hline
\end{tabular}

\subsubsection{Tools:}

In order to collect the necessary data for the study, the following two tools were used:-

\section{Tool (I): Students assessment:-}

It was developed by the researchers after a review of relevant literature to collect the required data. It composed of 4 parts as follows:-

Part 1: It included assessment of the students' characteristics:-

- Personal data: - student's age, academic year, birth order, and number of siblings.

- Assessment of students' general health condition; presence of health problem. (This information from the student's school health record)

Part 2: it included anthropometric measurements

- Anthropometric measurements were done by the researchers including; measuring of weight and height for students according to criteria described by Jelliffe. [22] Body Mass Index (BMI) was calculated using the following equation: [BMI=weight $(\mathrm{kg}) /$ height $(\mathrm{m}) 2$ ] then interpreted based on WHO growth reference/standards cut-off points for adolescents (5-19 years) using BMI-forage $\mathrm{Z}$-score. Where, $\mathrm{Z}$-score refers to the individual value as differences form the median value of the reference population in standard deviation (SD) units or Z-score units. [23]

- Based on BMI-for-age standard, students were classified as:

- Thin if BMI-for-age score was below -2 SD and severe thinness if below $-3 \mathrm{SD}$.

- Overweight, obese and severely obese if BMI-forage score was above $1 \mathrm{SD}, 2 \mathrm{SD}, 3 \mathrm{SD}$; respectively.

Part 3: it included Students' life styles

- Students' life styles: - as feeding pattern, sleeping pattern ,smoking, sports and work status.

A scoring system was developed with respect to students' feeding pattern as follows:-

- Number of meals (one $=1$, two $=2$, three $=3$, four $=4$ )

- Intake of breakfast, snacks and taking sandwiches to school (never $=1$, sometimes $=2$, always $=3$ )

- Intake of fast food (never=3, sometimes=2, always $=1$ )

Part 4: it included students' academic performance

- Students' academic performance: - Study hours, putting study schedule, private tutoring, finishing daily homework, problems during study, study alone, number of academic failure years.

Tool II: it included the following:-

Part I: Family Socioeconomic Status Scale (SES)

This scale was generated in 1983 by Fahmy and ElSherbini then; it was updated and validated by El-Gilany, El-Wehady and El-Wasify in 2012. [24] in English language. It was translated into Arabic language by the researchers. The SES scale composed of seven domains as illustrated in the following:

- Educational and cultural domain for both husband and wife (30 scores)

- Occupation for both husband and wife (10 scores)

- Family domain (10 scores)

- Family possessions domain (12 scores)

- Home sanitation domain (12 scores)

- Economic domain (5 scores)

- Health care domain (5 scores)

Creating a total SES score of 84 and the socioeconomic level was classified into four levels based on the quartiles as follows:

$\begin{array}{ll}\text { Very low } & <25 \% \\ \text { Low } & 25 \%-<50 \% \\ \text { Middle } & 50 \%-<75 \% \\ \text { High } & \geq 75 \%\end{array}$

In case of death or retirement of husband or wife, the education and occupation before death or retirement were recorded.

Part II: Strengths and Difficulties Questionnaire (SDQ) $[25,26,27]$

SDQ is a brief emotional/behavioral screening questionnaire of children and adolescents (about 11-17 years old) developed by Goodman in 1999 then translated into many languages including Arabic and validated by Alyahri A. et al in 2006.

- It was developed to assess the behavioral, emotional and social problems among students which help in 
identifying the association between the presence of these problems and academic underachievement.

- SDQ contains 25 items categorized into five scales of five items per each which are; (hyperactivity/inattention, emotional symptoms, conduct problems, peer relationship problems and prosocial behavior) that contains both positive and negative behavioral traits.

- Responses to each of the 25 items consist of three options: not true, somewhat true, or certainly true. For all scales the items that are worded negatively are assigned scores of 2 for certainly true, 1 for somewhat true, and 0 for not true which is reversed for positive items $(7,11,14,21,25)$.

- For each of the 5 scales the scores can range from $0-10$. The total difficulties score ranging from 0 to 40 which is generated by summing of all subscales except the pro-social scale that represent the interpersonal interaction and concern for others which is scored separately, as shown in the following table:-

Table 2. The total score of Strengths and Difficulties Questionnaire (SDQ)

\begin{tabular}{|l|c|c|c|}
\hline Score of scales & Normal & Borderline & Abnormal \\
\hline Total difficulties score & $\mathbf{0 - 1 5}$ & $\mathbf{1 6 - 1 9}$ & $\mathbf{2 0 - 4 0}$ \\
\hline Emotional & $0-5$ & 6 & $7-10$ \\
\hline Conduct & $0-3$ & 4 & $5-10$ \\
\hline Hyperactivity & $0-5$ & 6 & $7-10$ \\
\hline Peer problem & $0-3$ & $4-5$ & $6-10$ \\
\hline Prosocial & $6-10$ & 5 & $0-4$ \\
\hline
\end{tabular}

\subsection{Method}

\subsubsection{Administrative Phase}

- An official letter was directed from the Faculty of Nursing, University of Damnhour to the Central Administration for Public Mobilization and Statistics (CAPMAS) and the Directorate of Education in El-Beheira Governorate to obtain their permission to collect data from the selected schools.

- Approval letters directed from the Directorate of Education in El-Beheira Governorate to directors of the selected five Educational Directorates.

- Meeting was held with directors of the selected schools to clarify the purpose of the study and to gain their cooperation during data collection.

\subsubsection{Development of the Study Tools}

- The tool (I) were developed by the researchers, revised and validated after reviewing of the recent literature.

- Tool II was translated into Arabic by the researchers

- The tools were revised by a jury composed of five experts in the field of community health nursing and pediatric nursing for content validity and recommended modifications were done accordingly.

- Test-retest reliability was conducted on 40 students (20 achievers and 20 underachievers) for SES \& SDQ where the correlation coefficient was 0.980 , 0.8008 , and 0.930 respectively.

\subsubsection{Pilot Study}

- A pilot study was carried out in order to ascertain the relevance, clarity and applicability of the tools, test wording of the questions, and estimate the time required for the interview. It was conducted on a sample of 40 students $(20$ achievers and 20 underachievers). They were selected randomly from another setting not included in the original study settings namely El-Rahmania and Hosh-Eisa.

- The data obtained were analyzed and necessary modifications were done accordingly.

\subsubsection{Selection of the Schools}

- El-Beheira Governorate includes eighteen educational directorates, from which five were selected randomly. From each selected directorate two governmental general preparatory schools were chosen randomly (one male and one female school).

\subsubsection{Selection of the Subjects}

- Using systematic random sample technique, 40 students (20 underachievers and 20 achievers) enrolled in the second and third grades from each of the selected schools during the academic year (2016-2017) were included in the study. The interval was calculated for achiever and underachiever students in each school separately by dividing the total number of achiever and underachiever students in the second and third grade by the required number of students to select the required sample size which is 200 underachiever and 200 achiever students.

- Prior to data collection, research written consent from the directors of each school was obtained to assume the protection of human rights of the subjects

\subsubsection{Data Collection}

- The data was collected individually from the students in their schools after a brief explanation of the purpose and nature of the study. The students were asked for an oral consent for participation in the study. They were informed that their participation is completely voluntary and assured them that the collected data will be used only for the purpose of the study.

- Confidentiality of data was maintained and anonymity of individual responses was guaranteed through using a code numbers instead of names.

- The interview took approximately 45-75 minutes for each student.

- Students' weight was measured using a standardized weighing scale, in kilograms to the nearest $0.5 \mathrm{Kg}$.

- Students' height was measured using a non-stretching tape, in centimeters to the nearest $0.1 \mathrm{~cm}$.

- Data was collected on the academic year (20162017) over a period of 5 months (from January to May 2017).

\subsubsection{Data Analysis (Statistical Analysis)}

- After data collection, data was coded and transferred into especially designed formats to be suitable for computer feeding. 
- Following data entry, checking and verifying process were carried out to avoid any errors during data entry. Frequency analysis, cross tabulation and manual revision were all used to detect any errors.

- Data was analyzed using the Statistical Package of Social Science (SPSS) version 20.

- The level of significance selected for this study was $P$ value equal to or less than 0.05 .

- The variables were analyzed using descriptive statistics which included percentages, frequencies, range (minimum and maximum), arithmetic mean, standard deviation, Statistical tests as chi square test (X2) was used to test the association between two qualitative variables or to detect difference between two or more portions.

- P-value was used whenever the expected frequency of any cells in the tables falls below 5 .

- Two sample t-test is a parametric test for comparing means of two independent groups. It is used for continuous variables.

- Step-wise regression was done to identifying the best predictors for the outcome.

\section{Results}

Table 3 Illustrates Socio-demographic characteristics of achiever and underachiever students. Regarding age, it ranged from 12-16 years with a mean age of (14.23 \pm 1.36 ) for achiever students. Where, under-achiever students were ranged from 12-17 years with a mean of $(15.15 \pm 1.21)$. More than half $(55 \%)$ of achiever students and approximately half (44\%) of underachiever students were aged between 14 to less than 15 years, with a statistically significant difference between both groups $\left(\mathrm{X}^{2}=14.44, \mathrm{p}=0.0023\right)$. Regarding the academic grade, around three quarters $(70 \% \& 74.5 \%)$ of the achievers and underachievers groups were enrolled in the second grade of preparatory schools while the rest of both groups were enrolled in the third grade $(30 \% \& 25.5 \%)$ respectively, with no statistically significant difference between both groups $\left(\mathrm{X}^{2}=1.01, \mathrm{P}=0.314\right)$. Pertaining to number of siblings, the mean number of siblings were $(2.82 \pm 2.11)$ for achievers group and $(4.22 \pm 3.02)$ for underachievers group. Furthermore it is revealed from the same table that, more than half $(55.5 \%)$ of achiever students were ranked as the first child compared to only one fifth (21.5\%) for underachiever students. There were a statistically significant difference between both groups $\left(X^{2}=60.78\right.$, $\mathrm{p}=0.0001$ ).

Figure 1 portrays the distribution of the studied students according to their total Socioeconomic Scale (SES). It is apparent from the figure that about two thirds $(68 \%)$ of underachievers group had low socioeconomic status compared to more than one quarter $(25.5 \%)$ of achievers group. However, only (4.0\%) of underachievers group versus more than tenth $(16.0 \%)$ of achievers group had high socioeconomic status. A statistically significant difference was found between both groups with respect to their socioeconomic status where ( $\mathrm{t}$ - test $=11.17, \mathrm{P}=0.000^{*}$ ).

Table 3. Socio-demographic characteristics of achiever and underachiever students $(n=400)$

\begin{tabular}{|c|c|c|c|c|c|}
\hline \multirow[t]{2}{*}{ Students characteristics } & \multicolumn{2}{|c|}{$\begin{array}{c}\text { Achievers } \\
(\mathbf{n}=\mathbf{2 0 0})\end{array}$} & \multicolumn{2}{|c|}{ Underachievers $(n=200)$} & \multirow{2}{*}{$\begin{array}{c}\mathrm{X}^{2} \text { test } \\
\text { p-value }\end{array}$} \\
\hline & No. & $\%$ & No. & $\%$ & \\
\hline \multicolumn{6}{|l|}{ Age (in years) } \\
\hline $12-$ & 8 & 4 & 4 & 2 & \\
\hline $13-$ & 17 & 8.5 & 8 & 4 & \\
\hline $14-$ & 110 & 55 & 88 & 44 & $\begin{array}{c}14.44 \\
0.0023^{*}\end{array}$ \\
\hline$\geq 15$ & 65 & 32.5 & 100 & 50 & \\
\hline Min-Max & \multicolumn{2}{|c|}{$12.0-16.0$} & \multicolumn{2}{|c|}{$12.0-17.0$} & \\
\hline Mean \pm SD & \multicolumn{2}{|c|}{$14.23 \pm 1.36$} & \multicolumn{2}{|c|}{$15.15 \pm 1.21$} & \\
\hline \multicolumn{6}{|l|}{ Academic year } \\
\hline Grade 2 & 140 & 70 & 149 & 74.5 & 1.01 \\
\hline Grade 3 & 60 & 30 & 51 & 25.5 & 0.314 \\
\hline \multicolumn{6}{|l|}{ Number of siblings } \\
\hline None & 17 & 8 & 1 & 0.5 & \\
\hline $1-$ & 41 & 20.5 & 10 & 5 & \\
\hline $2-$ & 103 & 51.5 & 45 & 22.5 & \\
\hline $3-$ & 37 & 18.5 & 94 & 47 & 82.65 \\
\hline 4- & 2 & 1 & 40 & 20 & $0.0001^{*}$ \\
\hline$\geq 5$ & 1 & 0.5 & 10 & 5 & \\
\hline Min-Max & \multicolumn{2}{|c|}{$0-6$} & \multicolumn{2}{|c|}{$0-8$} & \\
\hline Mean \pm SD & \multicolumn{2}{|c|}{$2.82 \pm 2.11$} & \multicolumn{2}{|c|}{$4.22 \pm 3.02$} & \\
\hline \multicolumn{6}{|l|}{ Birth order } \\
\hline $1^{\mathrm{st}}$ & 111 & 55.5 & 43 & 21.5 & \\
\hline $2^{\text {nd }}$ & 60 & 30 & 69 & 34.5 & \\
\hline $3^{\text {rd }}$ & 18 & 9 & 48 & 24 & $0.0001 *$ \\
\hline$\geq 4^{\text {th }}$ & 11 & 5.5 & 40 & 20 & \\
\hline
\end{tabular}

$\mathrm{X}^{2}$ : Chi-Square test

* Significant at $\mathrm{P} \leq 0.05$. 


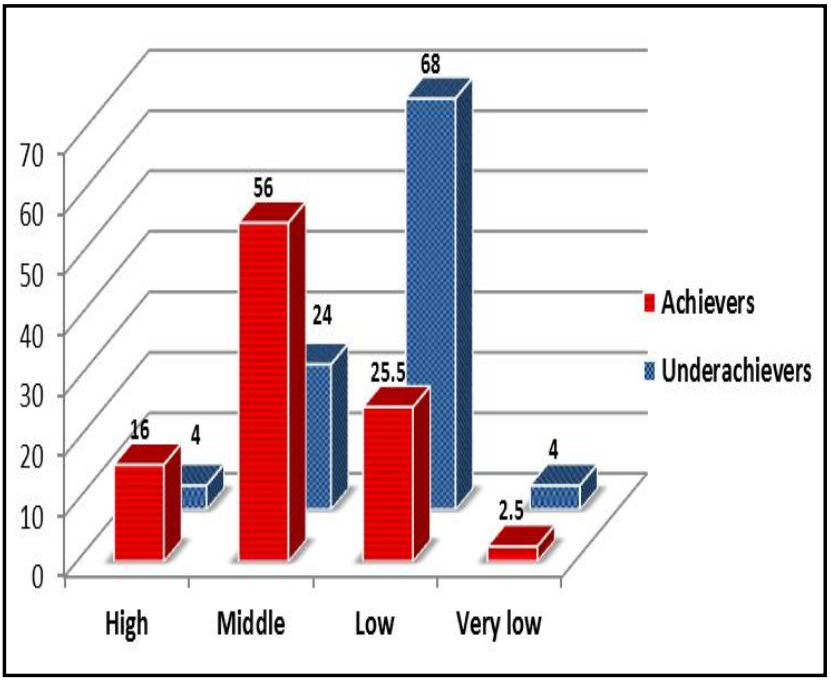

Figure 1. Distribution of the studied student according to their total socioeconomic Scale

Table 4 presents the distribution of the studied students according to their health condition. Less than one third $(31.0 \%)$ of achiever students reported that they had a health problem compared to more than half $(59.5 \%)$ of underachievers group with a statistically significant difference between both groups $\left(\mathrm{X}^{2}=32.78\right.$., $\left.\mathrm{P}=0.00001\right)$. Anemia was the most frequent health problem as it was reported by more than three quarters $(78.2 \%)$ of underachievers and more than two thirds $(69.3 \%)$ of achievers. Vision problem consider a second health problem as it was reported by more half $(52.9 \%)$ of underachievers and more than one third $(35.5 \%)$ of achievers. There was no statistically significant difference between both groups $\left(\mathrm{X}^{2}=1.15\right.$., $\left.\mathrm{P}=0.7658\right)$.

Table 4. Distribution of the studied students according to their health condition $(n=400)$

\begin{tabular}{|c|c|c|c|c|c|}
\hline \multirow{2}{*}{ Health condition } & \multicolumn{2}{|c|}{$\begin{array}{c}\text { Achievers } \\
(\mathbf{n}=\mathbf{2 0 0})\end{array}$} & \multicolumn{2}{|c|}{$\begin{array}{c}\text { Underachievers } \\
(\mathrm{n}=\mathbf{2 0 0})\end{array}$} & \multirow{2}{*}{$\begin{array}{c}\mathrm{X}^{2} \\
\text { p-value }\end{array}$} \\
\hline & No. & $\%$ & No. & $\%$ & \\
\hline \multicolumn{6}{|l|}{$\begin{array}{l}\text { Presence of health } \\
\text { Problems }\end{array}$} \\
\hline Yes & 62 & 31 & 119 & 59.5 & 32.78 \\
\hline No & 138 & 69 & 81 & 40.5 & $0.00001^{*}$ \\
\hline If yes \# & \multicolumn{2}{|c|}{$(n=62)$} & \multicolumn{2}{|c|}{$(n=119)$} & \\
\hline Anemia & 43 & 69.3 & 93 & 78.2 & \\
\hline Vision problem & 22 & 35.5 & 63 & 52.9 & \\
\hline Bronchial asthma & 14 & 22.6 & 28 & 23.5 & \\
\hline Parasitic disease & 5 & 8 & 10 & 8.4 & \\
\hline Rheumatic heart disease & 0 & 0 & 7 & 5.8 & \\
\hline Epilepsy & 1 & 0.1 & 1 & 0.8 & $\begin{array}{l}1.15 \\
0.7658\end{array}$ \\
\hline Skin disease & 1 & 0.1 & 1 & 0.8 & \\
\hline Digestive problems & 0 & 0 & 5 & 0.4 & \\
\hline Bone problems & 2 & 0.3 & 2 & 0.1 & \\
\hline Renal disease & 1 & 0.1 & 2 & 0.1 & \\
\hline Speech (Stuttering) & 0 & 0 & 3 & 0.2 & \\
\hline
\end{tabular}

$\mathrm{X}^{2}$ : Chi-Square test

* Significant at $\mathrm{P} \leq 0.05$

\# More than one answer.

Figure 2 portrays the distribution of the studied sample according to WHO growth reference standards using BMI for age. It was found that $56.0 \%$ \& $45.0 \%$ respectively of both achievers and under - achievers groups had normal BMI for age. On the other hand $28.5 \% \quad \& 30 \%$ respectively of both achievers and under - achievers students had over-weight. Obesity constitutes only $14.5 \%$ and $12.5 \%$ respectively of both achievers and underachievers students with statistically significant difference between both groups $\left(X^{2}=22.38\right.$, $\mathrm{P}=0.0001$ ).

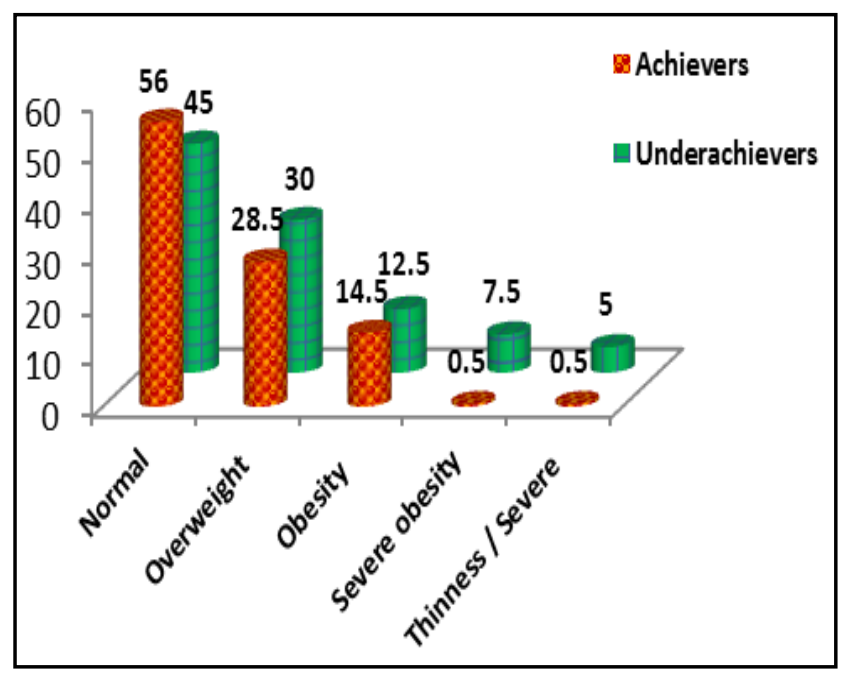

Figure 2. Distribution of studied students according to WHO Growth reference standards using BMI for age

Table 5 reveals the distribution of the studied students according to their lifestyles. Regarding the students' feeding pattern, it was found that half $(50 \%)$ of achievers group always taking breakfast compared to only approximately one third (31\%) of underachiever students while minority $(3.5 \%)$ of achiever students never taking breakfast compared to almost fifth (19\%) of underachiever students. A statistically significant difference was found between both groups with respect to intake of breakfast $\left(\mathrm{X}^{2}=30.52, \mathrm{P}<0.0001\right)$. Moreover, it was found that, more than half $(59 \%)$ of achiever students always taking sandwiches to school compared to only $16 \%$ of underachievers. There was a statistically significant difference $\left(\mathrm{X}^{2}=79.06, \mathrm{P}<0.00001\right)$.

Regarding feeding pattern score, it ranged from 50-60 among achievers and 23- 51 among underachievers. A statistically significant difference was found $(\mathrm{Z}=4.215$, $\mathrm{P}=0.00001)$. Concerning sleeping hours/night it was found that, it ranged from 5-12 hours for both achiever and underachiever students. Half $(50 \%)$ of achievers compared to more than one third $(36.5 \%)$ of under achievers reported that they had sleep for 8 to less than 10 hours/night with a statistically significant difference between both groups $\left(\mathrm{X}^{2}=27.50, \mathrm{P}<0.0001\right)$. Moreover, almost two thirds $(65.5 \%)$ of underachievers had sleep problems compared to more than one third $(35.5 \%)$ of achievers, with a statistically significant difference between both groups $\left(\mathrm{X}^{2}=36.0, \mathrm{P}<0.00001\right)$.

It is revealed also from the table that, only $6 \%$ of achiever students were smokers compared to one fifth $(20 \%)$ of underachiever students. Statistically significant difference between both groups was found $\left(\mathrm{X}^{2}=17.33, \mathrm{P}<0.00001\right)$. Regarding student working condition, it was clear from the table that, only $6 \%$ of achiever students were working compared to $42 \%$ of underachiever students. There was a 
statistically significant difference between both groups $\left(\mathrm{X}^{2}=71.05, \mathrm{P}<0.00001\right)$.

Academic performance is presented in Table 6 , regarding student study hours; it ranged from 1.5-7 hours for achiever students and underachiever students were ranged from 1-6 hours. Only $17.5 \%$ of achiever students reported that they study less than 2 hours / day compared to half $(50 \%)$ of underachiever's students. While $40 \%$, $37.5 \%$ respectively of achievers and under-achiever students study from 2 to less than 4 hours/day.

Concerning putting schedule for study, approximately half $(48.5 \%)$ of achiever students mentioned that they set schedule for study compared to only $21 \%$ underachiever students. Moreover, $70.5 \%$ of achiever students reported that they finishing daily homework compared to $37.5 \%$ underachiever students. Problems during study were mentioned by more than half $(52.5 \%)$ of achiever students compared to majority $(88.5 \%)$ of under achiever students.

Regarding private tutoring, more than three quarter $(77.5 \%)$ of achiever students attended private tutoring compared to more than half $(59.5 \%)$ of underachiever students. It was obvious from the table that only $2 \%$ of achiever students reported repetition of previous grade compared to more than one third $(38.5 \%)$ of underachiever's students

A statistically significant differences were observed between both groups with respect to study hours / day, putting study schedule, finishing daily homework, problem during study, private tutoring and previous grade repetition $\left(X^{2}=64.19, P=0.00001, X^{2}=21.66, P=0.0001\right.$, $X^{2}=43.84, P=0.00001, X^{2}=49.46, P=0.0001, X^{2}=15.02$, $\mathrm{P}=0.0001$ and $\mathrm{X}^{2}=82.50, \mathrm{P}=0.00001$ respectively).

Table 5. Distribution of the studied students according to their life style $(n=400)$

\begin{tabular}{|c|c|c|c|c|c|}
\hline \multirow[t]{2}{*}{ Feeding pattern } & \multicolumn{2}{|c|}{$\begin{array}{c}\text { Achievers } \\
(\mathbf{n}=\mathbf{2 0 0})\end{array}$} & \multicolumn{2}{|c|}{$\begin{array}{c}\text { Underachievers } \\
(\mathbf{n}=\mathbf{2 0 0})\end{array}$} & \multirow{2}{*}{$\underset{\text { p-value }}{\mathbf{X}^{2}}$} \\
\hline & No. & $\%$ & No. & $\%$ & \\
\hline \multicolumn{6}{|c|}{ Number of meals / day } \\
\hline One & 8 & 4 & 5 & 2.5 & \multirow{4}{*}{$\begin{array}{c}3.43 \\
0.3297\end{array}$} \\
\hline Two & 61 & 30.5 & 70 & 35 & \\
\hline Three & 122 & 61 & 110 & 55 & \\
\hline Four & 9 & 4.5 & 15 & 7.5 & \\
\hline \multicolumn{6}{|l|}{ Taking breakfast } \\
\hline No & 7 & 3.5 & 38 & 19 & \multirow{3}{*}{$\begin{array}{c}30.52 \\
0.00001 *\end{array}$} \\
\hline Sometimes & 93 & 46.5 & 100 & 50 & \\
\hline Always & 100 & 50 & 62 & 31 & \\
\hline \multicolumn{6}{|l|}{ Taking of snacks } \\
\hline No & 7 & 3.5 & 15 & 7.5 & \multirow{3}{*}{$\begin{array}{c}5.88 \\
0.0529\end{array}$} \\
\hline Sometimes & 121 & 60.5 & 131 & 65.5 & \\
\hline Always & 72 & 36 & 54 & 27 & \\
\hline \multicolumn{6}{|l|}{ Taking Fast food } \\
\hline No & 38 & 19 & 29 & 14.5 & \multirow{3}{*}{$\begin{array}{c}5.65 \\
0.0591\end{array}$} \\
\hline Sometimes & 121 & 60.5 & 110 & 55 & \\
\hline Always & 41 & 20.5 & 61 & 30.5 & \\
\hline \multicolumn{6}{|c|}{ Taking sandwiches to school } \\
\hline No & 40 & 20 & 77 & 38.5 & \multirow{3}{*}{$\begin{array}{c}79.06 \\
0.00001 *\end{array}$} \\
\hline Sometimes & 42 & 21 & 91 & 45.5 & \\
\hline Always & 118 & 59 & 32 & 16 & \\
\hline \multicolumn{6}{|c|}{ Feeding pattern score } \\
\hline Min-Max & \multicolumn{2}{|c|}{$50-60$} & \multicolumn{2}{|c|}{$23.0-51.0$} & \multirow{2}{*}{$\begin{array}{c}\mathrm{t} \text { test } \\
0.001 *\end{array}$} \\
\hline Mean \pm SD & \multicolumn{2}{|c|}{$56.0 \pm 2.26$} & \multicolumn{2}{|c|}{$34.0 \pm 5.68$} & \\
\hline \multicolumn{6}{|l|}{ Sleep } \\
\hline Sleeping hours / & & & & & \\
\hline$<6$ & 8 & 4 & 10 & 5 & \\
\hline $6-$ & 78 & 39 & 65 & 32.5 & 27.50 \\
\hline $8-$ & 100 & 50 & 73 & 36.5 & $0.0001^{*}$ \\
\hline $10-$ & 14 & 7 & 52 & 26 & \\
\hline Min-Max & & & & & \\
\hline Day naps (in hou & & & & & \\
\hline Yes & 73 & 36.5 & 61 & 30.5 & 1.62 \\
\hline No & 127 & 63.5 & 139 & 69.5 & 0.203 \\
\hline Presence of sleep & & & & & \\
\hline Yes & 71 & 35.5 & 131 & 65.5 & 36.0 \\
\hline No & 129 & 64.5 & 69 & 34.5 & $0.0001 *$ \\
\hline Smoking & & & & & \\
\hline Students' smoki & & & & & \\
\hline No & 188 & 94 & 160 & 80 & 17.33 \\
\hline Yes & 12 & 6 & 40 & 20 & $0.0001 *$ \\
\hline Sport & & & & & \\
\hline Practicing sport & & & & & \\
\hline Yes & 124 & 62 & 88 & 44 & 13.01 \\
\hline No & 76 & 38 & 112 & 56 & 0.0003 \\
\hline Student's labor & & & & & \\
\hline Work status & & & & & \\
\hline Yes & 12 & 6 & 84 & 42 & 71.05 \\
\hline No & 188 & 94 & 116 & 58 & $0.0001 *$ \\
\hline
\end{tabular}

$\mathrm{X}^{2}$ : Chi-Square test, t: independent samples $\mathrm{t}$ test, *Significant at $\mathrm{P} \leq 0.0$ 
Table 6. Distribution of the studied students according to their academic performance $(n=400)$

\begin{tabular}{|c|c|c|c|c|c|}
\hline \multirow[t]{2}{*}{ Academic performance } & \multicolumn{2}{|c|}{$\begin{array}{c}\text { Achievers } \\
(\mathbf{n}=200)\end{array}$} & \multicolumn{2}{|c|}{$\begin{array}{c}\text { Underachievers } \\
(n=200)\end{array}$} & \multirow{2}{*}{$\begin{array}{c}\mathbf{X}^{2} \\
\text { p-value }\end{array}$} \\
\hline & No. & $\%$ & No. & $\%$ & \\
\hline \multicolumn{6}{|l|}{ study hours/day } \\
\hline$<2$ & 35 & 17.5 & 100 & 50 & \multirow{5}{*}{$\begin{array}{c}64.19 \\
0.00001 *\end{array}$} \\
\hline $2-$ & 80 & 40 & 75 & 37.5 & \\
\hline $4-$ & 75 & 37.5 & 22 & 11 & \\
\hline $6-$ & 10 & 5 & 3 & 1.5 & \\
\hline Min- Max & \multicolumn{2}{|c|}{$1.5-7.0$} & \multicolumn{2}{|c|}{$1.0-6.0$} & \\
\hline \multicolumn{6}{|l|}{ Putting study schedule } \\
\hline Yes & 97 & 48.5 & 52 & 21 & 21.66 \\
\hline No & 103 & 51.5 & 148 & 79 & $0.00001 *$ \\
\hline \multicolumn{6}{|l|}{ Finishing daily homework } \\
\hline Yes & 141 & 70.5 & 75 & 37.5 & 43.84 \\
\hline No & 59 & 29.5 & 125 & 62.5 & $0.00001 *$ \\
\hline \multicolumn{6}{|l|}{ Study alone } \\
\hline Yes & 151 & 75.5 & 145 & 72.5 & 0.47 \\
\hline No & 49 & 24.5 & 55 & 27.5 & 0.494 \\
\hline \multicolumn{6}{|l|}{ Problems during study } \\
\hline Yes & 105 & 52.5 & 177 & 88.5 & 49.46 \\
\hline No & 95 & 47.5 & 32 & 11.5 & $0.0001 *$ \\
\hline \multicolumn{6}{|l|}{ Private tutoring } \\
\hline Yes & 155 & 77.5 & 119 & 59.5 & 15.02 \\
\hline No & 45 & 22.5 & 81 & 40.5 & $0.0001 *$ \\
\hline \multicolumn{6}{|l|}{ Previous grade repetition } \\
\hline Yes & 4 & 2 & 77 & 38.5 & 82.50 \\
\hline No & 196 & 98 & 123 & 61.5 & $0.00001 *$ \\
\hline
\end{tabular}

$\mathrm{X}^{2}$ : Chi-Square test, *Significant at $\mathrm{P} \leq 0.05$.

Table 7 shows the relation between the students' academic achievement and mean score of their emotional, behavioral and social difficulties (SDQ). It is obvious from the table that the mean of emotional problems, hyperactivity \& inattention, conduct problems and peer relationship problems were low among achiever students $(4.54 \pm 2.18,4.35 \pm 1.54,3.04 \pm 1.57$, and $3.19 \pm 1.43)$ than underachiever students $(5.55 \pm 2.11,5.01 \pm 1.28$, $3.33 \pm 2.01$ and $4.10 \pm 1.51)$ respectively. However, prosocial manifestations were slightly less encountered among underachiever students $7.45 \pm 2.01$ than achiever students $7.67 \pm 1.59$. Furthermore, a statistically significant relation was existed between student' academic achievement level and each of emotional problems (t-test=2.36, $\mathrm{P}=0.013$ ), hyperactivity \& inattention (t-test=1.91, $\mathrm{P}=0.046)$, peer relationship problems (t-test=2.69, $\mathrm{P}=0.011$ ).

Regarding the liner regression model for the predictors of academic achievement among the studied students Table 8 portrays, the following variables show a significant effect, Students' age, Socioeconomic score, Students' labor, Finishing daily homework, Private tutoring, Years of previous grade repetition and Total strengths and difficulties score.

Table 7. Relation between the students' Academic achievement and mean score of their emotional, behavioral and social difficulties (SDQ)

\begin{tabular}{|c|c|c|c|c|}
\hline \multirow{2}{*}{ SDQ } & \multicolumn{2}{|c|}{ Academic achievement } & \multirow{2}{*}{ t-test } & \multirow{2}{*}{ (p value) } \\
\cline { 2 - 5 } & Achievers & Underachievers & & \\
\cline { 2 - 5 } & Mean \pm SD & Mean \pm SD & & \\
\hline Emotional problems & $4.54 \pm 2.18$ & $5.55 \pm 2.11$ & 2.36 & $0.013^{*}$ \\
\hline Hyperactivity \& inattention & $4.35 \pm 1.54$ & $5.01 \pm 1.28$ & 1.91 & $0.046^{*}$ \\
\hline Conduct problems & $3.04 \pm 1.57$ & $3.33 \pm 2.01$ & 0.985 & 0.465 \\
\hline Peer R/S problems & $3.19 \pm 1.43$ & $4.10 \pm 1.51$ & 2.69 & $0.011^{*}$ \\
\hline Prosocial behavior & $7.67 \pm 1.59$ & $7.45 \pm 2.01$ & 0.58 & 0.95 \\
\hline
\end{tabular}

$\mathrm{t}$ : independent samples $\mathrm{t}$ test, $*$ Significant at $\mathrm{p} \leq 0.05$.

Table 8. Linear regression model for predictors of academic achievement among the studied students

\begin{tabular}{|c|c|c|c|c|}
\hline Variables & B & S.E. & $\mathbf{T}$ & $P$ value \\
\hline Students' age (years) & 0.213 & 0.125 & 2.01 & $0.021 *$ \\
\hline Socioeconomic score & 0.301 & 0.206 & 1.98 & $0.033^{*}$ \\
\hline Students' labor (no/yes) & 0.108 & 0.116 & 2.21 & 0.014* \\
\hline Finishing daily homework (no/yes) & 0.521 & 0.253 & 2.65 & $0.005 *$ \\
\hline Private tutoring (no/yes) & 0.332 & 0.321 & 1.99 & $0.031 *$ \\
\hline Years of previous grade repetition & 0.405 & 0.142 & 3.07 & $0.0065^{*}$ \\
\hline Total strengths and difficulties score & 0.086 & 0.068 & 3.11 & $0.005 *$ \\
\hline Constant & 1.06 & & & $0.001 *$ \\
\hline
\end{tabular}

Model significance: $\mathrm{F}=38.9$; Adjusted $\mathrm{R}^{2}$ (coefficient of determination) $=0.681$; $\mathrm{SE}$ : standard error of estimate; B: unstandardized coefficient; t:independent samples t test; * Significant at $\mathrm{P}<0.05$. 


\section{Discussion}

Adolescents' academic underachievement is a multifactorial problem with complex and interrelated risk factors. It is the net product of the interaction between individual, family, school, and community risk factors. Identifying risk factors for underachievement among adolescents is the most essential step in structuring functional prevention, reversal and intervention strategies to decrease the burden of adolescents' underachievement in the community. [28] Accordingly, the present study was done with the aim of identifying Risk Factors of academic underachievement among preparatory school students in El-Behira Governorate.

There are a myriad of individual risk factors which can shape educational outcomes. The influence of students' age on performance has been investigated in a number of studies. The results of the present study showed that students' age was a significant predictor of scholastic achievement. In addition, the study proved that underachievers significantly had higher age than achievers. Similar findings were reported by Abubakar \& Oguguo (2012) and Naderi et al (2009). In contrast Mlambo (2012), and Trautmann \& Zepf (2011) who found that there was no significant relation between students' age and achievement. [29,32]

A large body of research has examined the linkages between siblings' variables and academic achievement which suggest that such linkage can be attributed to a variety of reasons including: decreased family resources with increasing the family size along with diminished parental monitoring and tough discipline. [33,34] The results of the current study revealed that underachievers were significantly had higher number of siblings than achievers. This result comes in lines with Hotz \& Pantano (2015), and Gorman (2014). [35,36] Otherwise, these results are contradicted with that of Sun Ha \& Lian Tam (2011), and Joseph (2009). [37,38] The researchers attributed that to the cultural difference where the number of children in the family will help in interactions, supports and financial assistance

Family socioeconomic status (SES) is one of the most important explanatory factors associated with health, cognitive and socio-emotional outcomes of students. The results of the current study portrayed that the family overall socioeconomic status was a significant predictor of students' scholastic achievement. The study also proved that underachievers were poorer than achievers; with a statistically significant relation between students' academic achievement and overall family SES. This comes in line with Bae (2014) [39], Ushie et al (2012) and Ahmar \& Anwar (2013) [40,41]. On the contrary, Igbo et al (2014) asserted that the overall parental socioeconomic background have no significant influence on the students' academic achievement. [42]

Adolescence stage is generally a healthy time of life, several important health problems either peak or start during these years. The results drawn from the current study showed that presence of health problems were significantly higher among underachievers than achievers. This was supported by Stephens (2014), and Forrest et al (2013) who stipulated that chronic health conditions that affect students' functional status were associated with poorer academic achievement. [43,44]
Based on findings of this study, anemia, and vision problems were the most prevalent health problems especially among the underachiever students. Iron deficiency anemia is a formidable health challenge in developing countries and remains persistently high despite national programs to control this deficiency. In agreement More et al (2013) stated that scholastic performance, intelligent quotient and scores of mental balance, attention \& concentration, verbal memory and recognition were decreased in iron deficient adolescent as compared to the non-iron deficient. [45]

With regard to vision problems, it mainly originates in childhood and if undetected may result in severe ocular disabilities, and may also be accompanied by subtle cognitive impairments as during reading and writing. Nayak etal (2017) indicated that vision impairment has a negative effect on cognitive abilities, psychosocial behavior and academic achievement. [46,47]

Adolescence is a second chance for growth or catch-up growth for those children who have experienced nutritional deficiencies in early childhood. The present study revealed that there was a statistically significant relation between students' academic achievement and their BMI-for-age Z-score. This comes in agreement with. Zavodny (2013) found that underweight is negatively related to students' reading test scores and math teacher assessments. Otherwise, Abdelalim et al (2012) who showed that the students' test scores were not related to their BMI percentile. This may be attributed to that about half of the current study subjects had normally homogenous weight. $[48,49,50]$

Nutrition has a profound impact on cognitive functioning and academic outcomes. The results of the current study revealed that the mean score of students' feeding pattern was significantly lower among underachievers than achievers. In agreement Nyaradi et al (2015), Stea \& Torstveit (2014), and Adolphus et al (2013) reported significant negative associations between' dietary pattern score and their school grades. [51,52,53]

Physical activity among adolescents has been declined in the past three decades, giving rise to public health implications that include a growing prevalence of obesity along with chronic diseases. Results of the present study revealed that underachievers were less likely to practice sport than achievers. The study also proved a statistically significant relation between sport practicing and scholastic achievement. This comes in line with Hillman et al (2011) and So (2012). This can be explained by: those who engage in more physical activity have increased concentration and enhanced attention spans compared to their less active class mates. [54,55,56]

A growing body of evidence suggests that sleep plays a crucial role in children \& adolescents ' performance at school. The findings of the current study revealed that underachiever students had longer night sleep duration than achievers. In contrast, Stea et al (2014) postulated that there was a significant association between short sleeping time and achievement among adolescents. This may be attributed to the careless attitude of underachiever students toward studying and their oppositional attitude of escaping from studying by sleeping. [57,58,59]

Smoking may negatively influence not only the brain development and cognitive abilities of adolescent but also 
their overall health and nutritional status. The results of the current study portrayed that underachievers were more likely to be smokers than achievers. In agreement with Idrizovic et al (2015), and Latvala et al (2014), as they revealed that the majority of low achievers were smokers. $[60,61]$

A vast body of work examines the impact of child labor on students' academic performance. The current study showed that students' work status was a significant predictor of academic achievement. The study also showed that child labor was more encountered among underachievers than achievers. In addition, the study proved a statistically significant relation between child labor and academic achievement. This agreed with Holgado et al (2014). This may be due to decreased working students' inclusion in the educational system, as a result of the fatigue produced by the labor. [62,63,64]

Proper study habits help in upgrading the underachiever students. Nadeem et al (2014) postulated that academic achievement of adolescents is positively and significantly related to their study habits. As regards study hours, the results of the current study revealed that students' average study hours per day were significantly lower among underachievers than achievers. This is in line with Bugge \&Wikan (2014) and $\mathrm{Ng}$ et al (2015). Additionally the present study showed that daily homework finishing is a significant predictor of students' academic achievement. The study also revealed that underachievers were less likely to complete their homework on daily basis than achievers. Similarly, Shashidhar et al (2009), \& Xu (2009) postulated that not performing regular homework contributed to scholastic backwardness. [65,66,67,68,69]

Private tutoring is being practiced at an alarming scale in Egypt and in many other developing countries. Nonetheless, studies on tutoring are still scant. The present study revealed that private tutoring was a significant predictor of students' academic achievement. In addition, the study proved that tutoring was significantly lower among underachievers than achievers. This comes in line with Ali et al (2013). Conversely, Berberoglu et al (2010) found no relation between private tutoring and academic achievement. This may be attributed to the poor socioeconomic status of underachievers which deprive them from private tutoring that can improve their academic performance. [70,71,72]

Furthermore, the findings of the present study illustrated that students' previous grade repetition was a significant predictor of scholastic achievement. In addition, the study proved that grade repetition was significantly more encountered among underachievers than achievers. Consistent findings were portrayed by Jimerson \& Ferguson (2007)' and Mertens et al (2009), as their studies indicated that students' perception of their educational experiences generally influences their motivation to perform in school. [73,74]

Finally academic underachievement is a final common pathway that may result from multiple etiologies and takes many different forms. Using Strengths and Difficulties Questionnaire (SDQ) to detect emotional, behavioral, and social difficulties among adolescents, the results of the current study proved that total SDQ difficulties score was a significant predictor of students' scholastic achievement. The study also revealed that difficulties were more encountered among underachievers than achievers. This comes in line with Hossain (2013) who proved that academic achievement had considerable negative and significant relationship with all the attributes behavioral problems in SDQ scale. Further support was provided by Tempelaar et al (2014) who found that adolescents with mental health problems perform less in school. [75,76,77]

\section{Conclusions}

Several personal risk factors were highlighted at the present study to have significant association with students' underachievement such as age, number of siblings, birth order, socioeconomic level, presence of health problems, and students' work status. In relation to students' lifestyles, a significant difference was observed between both achievers and underachievers groups in relation to number of sleeping hours per night, smoking, sport practicing and feeding habits. Moreover, a significant association between students' underachievement and their academic performance and study habits were revealed with respect to private tutoring, and previous grade repetition. Finally there is a significant association between students' underachievement and total strengths and difficulties score.

\section{Recommendations}

1. Developing evidence based guidelines for underachievement based on the underlying causes.

2. Develop monitoring system to identify high risk students for underachievement through school health insurance.

3. Campaigns to raise the awareness of the community about adolescents' underachievement in schools; its risk factors.

\section{References}

[1] United Nations Children's Fund (UNICEF). Progress for children; A report card on adolescents. USA: New York; 2012 [Cited 2014 Oct 11]. Available from: <www.unicef.org/publications>.

[2] WHO (2017). Adolescents: health risks and solutions. Fact sheet. Updated May 2017. Available from: http://www.who.int/mediacentre/factsheets/fs345/en/.

[3] Unicief 2015. Children in Egypt 2015. A statistical digest. Available from:

http://www.oosci-mena.org/uploads/1/wysiwyg/ Children_in_Egypt_2015.pdf.

[4] Mirowsky J, Ross C. Education, Social Status, and Health. New York, NY: Aldine de Gruyter; 2003.

[5] Karen J, Robert M, Hal B, Richard E. Nelson Essentials of pediatrics. $6^{\text {th }}$ ed. Canada: Saunders Elsevier; 2011.

[6] Badawi A, Al-Ghassani A, Jemni M, Masri M. Entrepreneurship Education in the Arab States. A joint project of UNESCO and the StratREAL Foundation, United Kingdom. Case Studies on the Arab States (Jordan, Tunisia, Oman and Egypt) and Regional Synthesis Report: UNESCO; 2010 [Cited 2014 March 20]. Available from: http://www.unesco.org/beirut.

[7] Nayak R, Mohanty N, Beriha S and Mohapatra S. Study of Risk Factors of Academic Underperformance in Rural School Children in a Coastal District of Odisha. Nayak, et al., J Child Adolesc Behav 2017, 5: 1.

[8] Balduf M. Underachievement among College Students. Fairfax county public schools. Journal of Advanced Academics 2009(20): 274-94. 
[9] Hanushek E, Woessmann L. The Economics of International Differences in Educational Achievement. Discussion Paper No. 4925. The Institute for the Study of Labor (IZA). Handbook of the Economics of Education. Amsterdam: North Holland; 2012.

[10] Population Council, Survey of Young People in Egypt (SYPE). Final Report, West Asia and North Africa Office; 2011 [Cited 2014 Feb 15]. Available from: http://www.popcouncil.org/uploads/pdfs/.

[11] Ministry of Education, General Administration for Information and Statistics, El-Beheira Governorate; 2015.

[12] Zsolani A. relationship between children's social competence, learning motivation and school achievement. Educational psychology 2012; 22(3):317-30.

[13] Voegeli S. Academic Underachievement: Understanding and Implications for Educators [Master thesis] in guidance and counseling. The Graduate School University of Wisconsin-Stout; 2008 [Cited 2014 Nov 20]. Available from http://www2.uwstout.edu/content/lib/thesis/2008/2008voegelis.pdf.

[14] Jeynes W. Family Factors and the Educational Success of Children. 2nd ed. USA; Routledge; Taylor \& Francis; 2010.

[15] Daniel K. Kipkemboi F. The impact of school environment and peer influences on students' academic performance in Vihiga County, Kenya. Journal of Education and Practice 2014; 11(5): $1-11$.

[16] Carlow B. Literature review on the support needs of parents of children with behavioral problems. Centre for social \& educational research, Dublin institute of technology. 2007 [Cited 2015 Oct 12]. Available from: http://www.dit.ie/cser/media/ditcser/images/.

[17] Quin J. Deris A. Bischoff G. Johnson J. The correlation between leadership, culture, and student achievement. The Online Journal of New Horizons in Education 2015; 5(2):54-62.

[18] American Nurses Association \& National Association of School Nurses. Scope and standards of practice - School nursing. 2nd ed. Silver Spring, MD: Nursesbooks.org. 2011.

[19] Eddy L. Caring for Children with Special Healthcare Needs and Their Families: A hand book for health professional. USA: WileyBlackwell; 2013.

[20] Nossier S (1983): A study of low achievement child on school age (6: 12 Years): Thesis submitted in partial fulfillment for master degree in psychiatry and neurology, Faculty of Medicine, Ain Shams University.

[21] Hassan E 1999. Epidemiology study of scholastic underachievement also among primary school children in Alexandria: prevalence and causes. Thesis, faculty of nursing, Alexandria University.

[22] Jelliffe B, Jelliffe P, Zerfas A. Newman GG. Community nutritional assessment. London: Oxford University Press; 1989.

[23] De-Onis M, Onyango W, Borghi E, Siyam A, Nishida C, Siekmann J. Development of WHO growth reference for schoolaged children and adolescents. Bull WHO. 2007; 85:660-7.

[24] El-Gilany A, El-Wehady A, El-Wasify M. Updating and validation of the socioeconomic status scale for health research in Egypt. Eastern Mediterranean Health Journal 2012; 18(9): 962-68.

[25] Goodman R, Meltzer H, Bailey V. The Strengths and Difficulties Questionnaire: A pilot study on the validity of the self-report version. European Child and Adolescent Psychiatry 1998; 7 : 125-30.

[26] Goodman R. The extended version of the Strengths and Difficulties Questionnaire as a guide to child psychiatric caseness and consequent burden. Journal of Child Psychology and Psychiatry 1999; 40: 791-801.

[27] Alyahri A. Goodman R. Validation of the Arabic Strengths and Difficulties Questionnaire and the Development and Well-Being Assessment. Eastern Mediterranean health journal 2006; 12 (2):138-46.

[28] Shashidhar S, Rao C, Hegde R. Factors Affecting Scholastic Performances of Adolescents. Indian Journal of Pediatrics 2009(76): 495-9.

[29] Abubakar R. Oguguo O. Age and gender as determinants of academic achievements in college mathematics. Asian journal of natural \& applied sciences 2012; 1(2): 203-13.

[30] Naderi H. Abdullah R. Aizan R. Sharir J. Kumar V. Creativity, age and gender as predictors of academic achievement among undergraduate students. Journal of American Science 2009; 5(5): $101-12$.
[31] Mlambo V. An analysis of some factors affecting student academic performance in an introductory biochemistry course at the University of the West Indies. Journal of Caribbean Teaching Scholar 2011; 1(2): 79-92.

[32] Trautmann M, Zepf F. Attentional performance, age and scholastic achievement in healthy children. Journal of PLOS ONE 2012; 7(3): $1-5$.

[33] Laird G, Shelton J. From an Adlerian Perspective: Birth order, dependency, and Bing drinking on a historically black University Campus. The Journal of Individual Psychology 2006; 62 (1): 18-35.

[34] Suleman Q, Hussain I, Akhtar Z. Effects of Family Structure on the Academic Performance of Students at Elementary Level in District Karak, Khyber Pukhtunkhwa (Pakistan). Journal of Sociological Research 2011; 2(3): 235-47.

[35] Hotz V. Pantano J. Strategic Parenting, Birth Order and School Performance. forthcoming in Journal of Population Economics 2015.

[36] Gorman L. Birth Order and Student Performance. EBSCO host Connection. NBER Digest 2014; p6.

[37] Sun Ha T, Lian Tam C. A Study of Birth Order, Academic Performance, and Personality. International Conference on Social Science and Humanity 2011(5): 28-32.

[38] Joseph T. Influence of Family Size and Family Birth Order on Academic Performance of Adolescents in Higher Institution. Pakistan Journal of Social Sciences 2009; 6 (3): 110-4.

[39] Bae D. Family socioeconomic status and academic achievement among korean adolescents. Linking mechanisms of family processes and adolescents' time use. The Journal of Early Adolescence September. 2014(11).

[40] Ushie A, Emeka O, Ononga I, Owolabi O. Influence of family structure on students' academic performance in Agege local government area, Lagos state, Nigeria. European Journal of Educational Studies 2012; 4(2): 177-87.

[41] Ahmar F, Anwar E. Socio economic status and its relation to academic achievement of higher secondary school students. Journal of Humanities and Social Science 2013; 6(13): 13-20.

[42] Igbo J, Okafor R, Eze J. The role of socio-economic background on self-concept and academic achievement of in-school adolescents in Nigeria. International Journal of Research in Humanities, Arts and Literature 2014; 2( 2): 1-10.

[43] Stephens S. Children with chronic health conditions less likely to graduate from high school. Journal of Adolescents Health 2014; (6): 1-12.

[44] Forrest C. Bevans K. Riley A. Crespo R. Louis L. Health and school outcomes during children's transition into adolescence. Journal of Adolescents Health 2013; 52(2):186-94.

[45] More S. Shivkumar B. Gangane N. Shende S. Effects of Iron Deficiency on Cognitive Function in School Going Adolescent Females in Rural Area of Central India. Hindawi Publishing Corporation 2013 (2013):1-5.

[46] Prajapati P, Oza J, Prajapati J, Kedia G, Chudasama K. Prevalence of Ocular Morbidity among School Adolescents of Gandhinagar District, Gujarat. Journal of Health \& Allied Sciences 2010; 9(4): 4-5.

[47] Nayak R, Mohanty N, Beriha S, Mohapatra S (2017) Study of Risk Factors of Academic Underperformance in Rural School Children in a Coastal District of Odisha. J Child Adolesc Behav 5: 332.

[48] Khopkar S, Virtanen S, Kulathinal S. Anthropometric characteristics of underprivileged adolescents: A study from urban slums of India. Journal of Anthropology. 2014; (2014): 1-9.

[49] Zavodny M. Does weight affect children's test scores and teacher assessments differently? Economic Education Review 2013; 34: 135-45.

[50] Abdelalim A, Ajaj N, Al-Tmimy A. Childhood obesity and academic achievement among male students in public primary schools in Kuwait. Med Princ Pract 2012; 21(1): 14-9.

[51] Nyaradi A, Hickling S, Foster K, Jacques A, Ambrosini L, Oddy $\mathrm{H}$. A Western dietary pattern is associated with poor academic performance in Australian adolescents. Nutrients 2015; 7(4): 2961-82.

[52] Stea T, Torstveit M. Association of lifestyle habits and academic achievement in Norwegian adolescents: a cross-sectional study. BMC Public Health 2014; (14): 1-8. 
[53] Adolphus K, Lawton L, Dye L. The Relationship between Habitual Breakfast Consumption Frequency and Academic Performance in British Adolescents Front Public Health 2015; 6(3): 68 .

[54] Hillman C, Kamijo K, Scudder M. A Review of Chronic and Acute Physical Activity Participation on Neuroelectric Measures of Brain Health and Cognition during Childhood. Prev Med 2011; 1 (52): 52-8.

[55] So W. Association between physical activity and academic performance in Korean adolescent students. BMC Public Health 2012; (12): 1-7.

[56] Dewald F, Meijer M, Oort J, Kerkhof A, Bogels M. The influence of sleep quality, sleep duration and sleepiness on school performance in children and adolescents: A meta-analytic review. Sleep Medicine Reviews 2010; 14: 179-89.

[57] Ming X, Koransky R, Kang V, Buchman S, Sarris C, Wagner G. Sleep insufficiency, sleep health problems and performance in high school students. Journal of Clinical Medicine Insights Circulatory Respiratory Pulmonary Medicine 2011; (5): 71-9.

[58] Mak K, Lee L, Ho Y, Lo S, Lam H. Sleep and academic performance in Hong Kong adolescents. Journal of School Health 2012; 82(11): 522-7.

[59] Stea H, Knutsen T, Torstveit K. Association between short time in bed, health-risk behaviors and poor academic achievement among Norwegian adolescents. Sleep Med 2014; 15(6): 666-71.

[60] Idrizovic K. Zenic N. Tahiraj N. Rausavljevic N. Sekulic D Cigarette smoking among 17-18 year old adolescents - prevalence and association with socio-demographic, familial, sport, and scholastic factors. Medycyna Pracy 2015; 66(2): 1-11.

[61] Latvala A. Rose J. Pulkkinen L. Dick M. Korhonen T. Kaprio J. Drinking, smoking, and educational achievement: cross-lagged associations from adolescence to adulthood. Drug Alcohol Depend 2014; 137(1):106-13.

[62] Fetuga B, Njokanma F, Ogunlesi A. Do working children have worse academic performance? Indian J Pediatr 2007; 74(10): 933-6.

[63] Sabia J. School-year employment and academic performance of young adolescents. Economics of Education Review 2009; 28 (2): 268-76.

[64] Holgado D, Maya-Jariego I, Ramos I, Palacio J, OviedoTrespalacios O, Romero-Mendoza V, Amar J. Impact of child labor on academic performance: Evidence from the program "Edu came Primero Colombia". International Journal of Educational Development 2014; (34) 58-66.
[65] Nadeem N, Ahamd J, Ahamd S. Study habits and academic achievement of Kashmiri \& Ladakhi adolescent girls: A Comparative Study. Turkish Online Journal of Distance Education-TOJDE 2014; 15(7): 91-7.

[66] Bugge L, Wikan G. Student Level Factors Influencing Performance and Study Progress. The Online Journal of New Horizons in Education 2014; 3(2): 30-8.

[67] $\mathrm{Ng} \mathrm{S}$, Zakariaa R, Laia S, Confessoreb G. A study of time use and academic achievement among secondary-school students in the state of Kelantan, Malaysia. International Journal of Adolescence and Youth 2015; (2): 1-16.

[68] Shashidhar S, Rao C, Hegde R. Factors affecting scholastic performances of adolescents. Indian Journal of Pediatrics 2009 (76): 495-9.

[69] Xu J. School location, student achievement, and homework management reported by middle school students. The School Community Journal 2009; 19(2): 27-44.

[70] Bagala B. Private tutoring and public corruption: a cost-effective education system for developing countries. The Developing Economies journal 2007; 37(2): 222-40.

[71] Ali S, Haider Z, Munir F, Khan H, Ahmed A. "Factors contributing to the students' academic performance: a case study of Islamia university sub-campus." American Journal of Educational Research. 2013; 1(8): 283-9.

[72] Berberoglu G, Demirtasl N, Best C, Arikan S, Libby Tuncer C. School of foreign relations of the student success factors: Effects on factors of out-of-school students' achievement. Cito Education: Theory and Practice 2010; 1 (7): 28-38.

[73] Jimerson S, Ferguson S. A Longitudinal study of grade retention: academic and behavioral outcomes of retained students through adolescence. School Psychology Quarterly 2007; 22( 3): 314-39.

[74] Mertens S, Anfara V, Roney K. An look at educating young adolescents. Motivational perspective 2009; (78):100-50.

[75] Shapiro k. Academic Underachievement: A neurodevelopmental perspective. Rev. Med. Clin. Condes 2011; 22(2): 212-17.

[76] Hossain S. A study of determining the relationship between academic achievement and problem behavior of urban secondary school students in Bangladesh. International journal of social sciences 2013; 8(1): 1-10.

[77] Tempelaar W, Otjes C, Bun C, Plevier C, Van Gastel W, MacCabe J, Kahn R, Boks M. Delayed school progression and mental health problems in adolescence: a population-based study in 10.803 adolescents. Journal of BMC Psychiatry 2014; 14(244): $2-6$ 